\title{
HUBUNGAN PRILAKU CARING PERAWAT DENGAN TINGKAT KEPUASAN ORANG TUA DI RUANG RAWAT INAP ANAK
}

\author{
The Relationship Of nursing behaviour caring with satisfaction level of prent's in child \\ care room
}

\author{
Roufuddin $^{1}$, Abd. Mannan², Mahardika Putri Kaonang ${ }^{3}$, Virki Widoyanti ${ }^{4}$ \\ ${ }^{1.2 .3 .4}$ Prodi Keperawatan Stikes ABI Surabaya
}

Alamat Korespondensi : Prodi Keperawatan STIKES ABI

J1. Pumpungan III No. 29 Sukolilo Surabaya-Jawa Timur-Indonesia

Email : roufuddin20@gmail.com

\begin{abstract}
ABSTRAK
Perilaku caring merupakan suatu sikap yang dilakukan oleh perawat dimana terdapat interaksi antara perawat dan penerima layanan didasari oleh sikap tanggung jawab, saling mendukung dan menghargai.Perilaku caring yang dianggap penting untuk dilakukan perawat guna memberikan kepuasan, tidak hanya bagi pasien dan keluarga pasien tetapi juga bagi perawat.Tingkat kepuasan orangtua merupakan Tingkat terpenuhinya kebutuhan dan keinginan yang sesuai atau melebihi harapan orangtua terhadap pemberian pelayanan keperawatan yang diberikan selama anak dirawat di ruang rawat inap anak.Penelitian ini bertujuan untuk mengetahui hubungan perilaku caring perwat dengan tingkat kepuasan orangtua di ruang rawat inap anak Puskesmas Blega Kabupaten Bangkalan.Desain penelitian yang digunakan adalah korelasional dengan pendekatan cross sectional sampel dipilih menggunakan teknik total sampling dengan 37 responden.Hasil pengujian korelasi didapatkan nilai sig sebesar 0,000 dan nilai korelasi sebesar 0,592 . Nilai tersebut $<0,05$ sehingga hipotesis yang menyatakan terdapat hubungan yang cukup kuat antara perilaku caring perawat dan tingkat kepuasan orangtua diterima. Hasil penelitian tersebut diharapkan perawat dapat meningkatkan pelayanan keperawatannya terutama perilaku caring nya sehingga pasien dan keluarga pasien akan merasa lebih puas akan pelayanan yang diberikan oleh fasilitas kesehatan tersebut. Misalnya dengan melakukan pengembangan SDM seperti mengikuti pelatihan untuk mengembangkan softskill-nya.
\end{abstract}

Kata kunci :caring, perawat, Tingkat kepuasan, orangtua, ruang anak

\section{ABSTRACT}

Caring behavior is an attitude performed by nurses where there is interaction between nurses and patient or family based on the responsibility, mutual support and appreciation. Caring behavior that is considered important to be done for nurses in providing satisfaction, not only for patients, their family, but also for nurses to provide satisfaction, nor patients and families, but also for nurses.The level of child parents satisfaction means the level of fulfillment of needs and desires which appropriate or more than parent's expectation to the nursing service that has been given in inpatient room for childin Puskesmas Blega kabupaten Bangkalan. The current design of this research used cross sectional approach of sample selected using total sampling technique with 37 respondents. The correlation test result obtained sig value of 0.000 and correlation value of 0,592. The value is $<0.05$ so that means there is a strong correlation between caring behavior on nurses and the level of parental satisfaction received. The result of the study, the caring behaviours on nurses is expected to be able to improve. so they maintaily to increase the level of patient-family satisfaction exspecially with which they served to them. Nurses can improve both the caring behavior and the level of infant statisfaction by participating in seminar or training to improve their softskill.

Keywords :caring, nurse, Level of satisfaction, Infants parents, Child Room 


\section{PENDAHULUAN}

Fasilitas pelayanan kesehatan dalam undang-undang No. 36 Tahun 2009, merupakan suatu tempat yang digunakan untuk menyelenggarakan upaya pelayanan kesehatan baik promotif, preventif, kuratif, maupun rehabilitatif yang dilakukan oleh pemerintah pusat, pemerintah daerah atau masyarakat umum. Kualitas pelayanan kesehatan ditentukan oleh mutu pelayanan yang diberikan kepada pasien serta strategi pelayanan rumah sakitnya. Salah satu strategi pelayanan rumah sakit yaitu melakukan pendekatan mutu pelayanan yang berorientasi kepada kepuasan pasien, kepuasan pasien tersebut dinilai mulai dari penerimaan pasien saat pertama kali datang, hingga saat pasien meninggalkan rumah sakit (Kemenkes, 2011)

Kualitas pelayanan keperawatan menjadi salah satu faktor yang dapat menentukan kualitas pelayanan kesehatan. Berdasarkan Keputusan Menteri Negara Pendayagunaan Aparatur Negara Nomor : 94/Kep/M.PAN/II/2001 BAB II pasal 4, menyebutkan bahwa tugas pokok perawat adalah memberikan pelayanan keperawatan berupa asuhan atau kesehatan kepada individu, keluarga, kelompok dan masyarakat dalam upaya kesehatan, pencegahan penyakit, penyembuhan penyakit, pemulihan dan pembinaan peran serta masyarakat dalam rangka kemandirian di bidang keperawatan atau kesehatan, yang menjadi salah satu faktor penentu citra institusi pelayanan kesehatan dimata masyarakat dan menunjukkan pelayanan keperawatan professional (Dwi, 2016).
Pelayanan keperawatan profesional ditetukan oleh keberadaan perawat secara kualitas dan kuantitas. Perawat adalah profesi yang paling mudah ditemui sebagai lapis terdepan dalam memberikan pelayanan kepada pasien (Aris, 2016). Dalam memberikan pelayanan, hubungan perawatpasien menjadi inti dalam pemberian asuhan keperawatan karena keberhasilan penyembuhan dan peningkatan kesehatan pasien sangat dipengaruhi oleh hubungan perawat-klien yang tergambar melalui perilaku caring perawat (Whatson.Jean, 2007). Dalam memberikan asuhan keperawatan seorang perawat dituntut untuk mempunyai sifat peduli(caring) terhadap keluhan pasien, tidak membeda-bedakan pasien, dan pemberian pelayanan yang tepat dan segera(Abdul saleh, 2013)

Caring adalah perhatian perawat dengan sepenuh hati tehadap pasien, kepedulian, empati, komunikasi yang lemah lembut dan rasa kasih sayang perawat kepada pasien akan membentuk hubungan perawatpasienyang terapeutik. Perilaku caring terhadap pasien merupakan suatu tindakan yang sangat penting bagi pasien. Perawat yang berperilaku selalu caringatau berperilaku caring baik terhadap pasiennya dapat memberikan kontribusi positif terhadap tingkat kepuasan pasien dalam menerima pelayanan keperawatan dan sebaliknya (Dwi, 2016)Proses caring melalui hubungan yang terapeutik ini harus muncul dalam diri perawat dimanapun perawat tersebut bertugas tidak terkecuali di ruang anak atau balita (Whatson.jean, 2007).Beberapa rumah sakit 
ruangan anak merupakan area steril dimana hanya tenaga kesehatan saja yang boleh masuk ke ruangan tersebut. Bahkan orangtua sebagai keluarga terdekat bagi bayi memerlukan izin khusus untuk masuk.Sebagai keluarga terdekat, orangtua terkadang merasa harus selalu mengetahui semua hal yang dilakukan kepada bayinya.Sehingga, apabila terjadi sesuatu dengan bayinya tidak jarang orangtua merasa cemas.Reaksi keluarga yang khawatir terhadap kondisi anak saat tidak mendampingi ini tidak jarang menyebabkan keluarga marah dan mengomel pada perawat jika keinginan mereka tidak terpenuhi.Penelitian menyatakan bahwa prediktor paling tinggi untuk terjadinya stres pada keluarga saat anggota keluarganya dirawat di General Intensif Care Unit RS Dr.Hasan Sadikin Bandung adalah sikap petugas kesehatan dalam pemberian informasi yang tidak adekuat. Kecemasan keluarga inilah yang nantinya akan mempengaruhi tingkat kepuasan atau penilaian mereka terhadap pelayanan keperawatan di rumah sakit (Chotimah, 2016).

Menurut keputusan menteri kesehatan No. 129 Tahun 2008 tentang Standar Pelayanan Minimal Rumah Sakit menyebutkan bahwa salah satu indikator penting dalam ruang perinatologi adalah kepuasan pasien atau keluarga harus lebih atau sama dengan 80\%.Kepuasan adalah tingkat keadaan yang dirasakan seseorang yang merupakan hasil dari membandingkan penampilan atau Outcome produk yang dirasakan dalam hubungannya dengan harapan seseorang (Wijono, 2010). Kepuasan pasien atau keluarga menjadi pusat dari hasil yang sedang diakui sebagai ukuran kualitas pelayanan perawatan. Dilihat dari perawatan berkualitas, kepuasan terhadap perawatan merupakan domain penting, terutama bagi pasien yang belum bisa membuat keputusan sendiri seperti bayi baru lahir, anak dibawah umur, pasien kritis, dan orang lanjut usia yang tidak memungkinkan untuk membuat keputusan sendiri. Sehingga tidak jarang pengambilan keputusan diserahkan kepada kelurga atau orang terdekat demi keselamatan pasien tersebut. Kepuasan pasien merupakan bentuk timbal-balik dari apa yang pasien dapatkan dalam pelayanan di rumah sakit (Wahyuni,2014).

Kepuasan pasien merupakan faktor yang sangat penting untuk mengevaluasi mutu pelayanan keperawatan yang dilakukan perawat di rumah sakit (Putri,2014). Kepuasan pasien di setiap ruangan pasti berbeda, salah satu faktor penyebab perbedaan tersebut adalah karakteristik serta kebutuhan pasien di setiap ruangan berbeda. Berdasarkan hasil penelitian yang dilakukan Putri (2014), kepuasan pasien di ruang rawat Inap RSUD Soeroto Ngawi sebesar 68,5\% pasien merasa puas dan $31,5 \%$ pasien merasa tidak puas terhadap perilaku caring yang dilakukan oleh perawat di rawat inap RSUD Soeroto Ngawi. Sedangkan pada penelitian Wahyuni (2014) tingkat kepuasan pasien di ruang bedah RS. Dr. Soepraoen Malang menyatakan bahwa terdapat 13,5\% kurang puas dan $5,8 \%$ tidak puas dengan perilaku 
perawat di ruangan tersebut. Tingkat kepuasan pasien di ruangan tersebut sangat berbeda, salah satu faktor yang dapat mempengaruhi tingkat kepuasan pasien adalah perilaku tenaga kesehatan (dalam hal ini perawat).Hal ini dibuktikan oleh hubungan (korelasi) yang nyata (signifikan) dan hubungan yang cukup kuat antara perilaku caring perawat dengan tingkat kepuasan pasien di ruang bedah RS. Dr. Soepraoen Malang (Wahyuni, 2014).

Dua penelitian sebelumnya dilakukan di rumah sakit pemerintah.Secara organisasi, rumah sakit pemerintah memiliki perbedaan dengan rumah sakit swasta.Rumah sakit pemerintah merupakan rumah sakit yang dimiliki pemerintah daerah maupun pemerintah pusat dan pendanaannya bersumber dari APBD/APBDN.Sementara itu, pendanaan rumah sakit swasta berasal dari pasien dan usaha lainnya. Walaupun aspek kepemilikan dan pendanaan berbeda, tetapi proses pelayanan yang diberikan harus tetap maksimal, karena hal ini berkaitan dengan citra rumah sakit. Pelayanan yang baik akan memberikan dampak terhadap kepuasan pasien (Kazemi et al. 2013). Peneliti tertarik meneliti di rumah sakit swasta karena secara logika peneliti, apabila pendanaan berasal dari pelanggan, maka harapan pasien terhadap fasilitas pelayanan swasta lebih besar dibandingkan dengan pelayanan di fasilitas negeri.

Berdasarkan hasil studi pendahuluan yang dilakukan di Puskesmas Blega Kabupaten Banggkalan didapatkan hasil bahwa pihak orangtua merasa kurang puas dengan pelayanan yang diberikan oleh pihak Puskesmas.Hal ini disebabkan karena beberapa faktor diantaranya sikap perawat yang kurang baik dan kesigapan perawat dalam menyelesaikan masalah dirasa kurang sesuai dengan harapan.

Sehingga, berdasarkan dua penelitian dan hasil studi pendahuluan diatas, peneliti tertarik untuk mengetahui hubungan antara perilaku caring perawat dengan orangtua yang dirawat di ruang rawat inap anak Puskesmas Blega Kabupaten Bangkalan. Peneliti tertarik untuk mengambil sampel di ruang anak dikarenakan ruangan tersebut merupakan ruangan yang dikhususkan bagi bayi baru lahir yang membutuhkan pelayanan keperawatan yang profesional.Sedangkan alasan pemilihan lokasi penelitian berdasarkan pertimbangan bahwa Puskesmas Blega Kabupaten Bangkalan merupakan Puskesmas rujukan yang memiliki ruang anak sendiri di Bangkalan. Sehingga peneliti tertarik untuk meneliti hubungan antara perilaku caring perawat terhadap tingkat kepuasan orangtua di ruang rawat inap anak Puskesmas Blega Kabupaten Bangkalan

\section{METODE}

Desain Penelitian

Desain penelitian ini adalah Observasional analitik dengan pendekatan Cross sectional.Data yang digunakan dalam penelitian ini adalah data primer.Penelitian ini bertujuan untuk mengetahui hubungan perilaku caring perawat dengan tingkat kepuasan orangtua di ruang anak. 
Sampel, Lokasi Penelitian dan Waktu Penelitian

Sampel dalam penelitian ini merupakan orangtua yang memiliki bayi dirawat di ruang rawat inap anak Puskesmas Blega Kabupaten Bangkalan.

Jumlah sampel yang dapat diambil sejumlah 37 responden yang diperoleh pada bulan Maret-Juni 2021.

Kriteria sampel penelitian adalah sebagai berikut :

a. Orangtua dengan bayi yang telah menjalani perawatan selama 1-3 hari di ruangan anak

b. Orangtua yang mendampingi bayi selama di Puskesmas

c. Orangtua yang bisa diajak berkomunikasi

d. Orangtua yang mampu membaca dan menulis

\section{Instrumen Penelitian}

Instrumen penelitian yang diigunakan oleh peneliti dalam penelitian ini adalah kuisioner dimana responden diminta menjawab pernyataan dengan memberikan tanda checklist $(\sqrt{ })$ pada jawaban yang sudah disiapkan oleh peneliti. Kulisioner yang akan diberikan kepada responden merupakan hasil modifikasi data perilaku caring perawat dan data tingkat kepuasan responden (orangtua) yang dirancang oleh peneliti. Untuk data perilaku caring didapatkan dari studi literature dan hasil modifikasi Watson 2010 terkait 10 carative factor dengan menggunakan caring factor survey.
Sedangkan, untuk data Tingkat kepuasan keluarga diukur menggunakan parameter 5 dimensi servqual (service Quality) model, yaitu : Kehandalan (realibility), Daya Tangkap (responsiveness), Jaminan (assurance), empati (Empathy) dan Wujud Fisik (Tangibles) (Parasuraman et al, 1998). Kuisioner kepuasan keluarga merupakan instrumen telah dimodifikasi oleh peneliti dari penelitian sebelumnya oleh Rovida (2015).

\section{HASIL DAN PEMBAHASAN}

Berdasarkan hasil penelitian dengan responden orangtua bayi, didapatkan data karakteristik yang berbeda-beda.karakteristik diamati berdasarkan jenis kelamin, usia, tingkat pendidikan, pekerjaan, dan status anak dalam keluarga yang ada di ruang perinatologi. Dari hasil penelitian dengan 37 responden berdasarkan jenis kelamin mayoritas memiliki jenis kelamin perempuan sebanyak 31 responden atau $(83,8 \%)$, hal ini sesuai dengan penelitian sebelumnya yang dilakukan oleh Matziou et al (2011) bahwa sebanyak 67,97\% dari responden penelitianya adalah ibu atau perempuan. Hal ini disebabkan karena ibu memiliki tingkat kecemasan yang lebih tinggi sehingga intensitas untuk ingin bertemu bayi mereka di ruangan lebih besar dibandingkan ayah (lakilaki). Berdasarkan usia responden paling rendah berusia 20 tahun dan paling tinggi berusia 40 tahun. Rata-rata usia responden secara keseluruhan adalah 29,84 dengan standar deviasi 4,89. 
Berdasarkan tingkat pendidikan, 15 responden berpendidikan SMA/SMK atau (40,5\%). Berdasarkan karakteristik pekerjaan responden mayoritas adalah ibu rumah tangga yaitu berjumlah 16 orang atau (43,2\%). Berdasarkan data karakteristik status anak dalam keluarga diketahui bahwa dari total 37 responden yang memiliki bayi, paling banyak merupakan anak ke- satu dan ke-dua dengan jumlah 15 orang (40,5\%). Hasil tersebut searah dengan penelitian yang dilakukan oleh Petros Galanis., et al (2016) dalam penelitiannya yang berjudul Factor associate with parents satisfaction with care provided in neonatal intensive care unit in Greece yang menyebutkan bahwa salah satu faktor yang dapat mempengaruhi penilaian kepuasan orangtua terhadap pelayanan yang diterima adalah status anak dalam keluaraga adalah anak pertama.

\section{Tabel 1. Distribusi Frekuensi Perilaku} Caring Perawat

\begin{tabular}{llc}
\hline Perilaku Caring & f & \% \\
\hline Cukup & 11 & 29,7 \\
Baik & 26 & 70,3 \\
\hline Total & $\mathbf{3 7}$ & $\mathbf{1 0 0 , 0}$ \\
\hline
\end{tabular}

Tabel di atas menunjukkan bahwa perilaku caring perawat sebanyak 26 orang adalah baik $(70,3 \%)$ dan 11 orang atau $(29,7 \%)$ menyatakan Cukup, sehingga berdasarkan data diatas dapat disimpulkan bahwa perilaku caring sebagian besar perawat dapat dikatakan baik.

\section{Tabel 2. Distribusi Frekuensi Tingkat} Kepuasan Orangtua

\begin{tabular}{lll}
\hline Tingkat Kepuasan & f & \% \\
\hline Cukup Puas & 3 & 8,1 \\
Puas & 12 & 32,4 \\
Sangat Puas & 22 & 59,5 \\
\hline Total & $\mathbf{3 7}$ & $\mathbf{1 0 0 , 0}$ \\
\hline
\end{tabular}

Dari hasil penelitian pada data tingkat kepuasan, sebanyak 22 orang (59,5\%) menyatakan bahwa mereka sangat puas dengan perilaku caring perawat, 12 responden atau $(32,4 \%)$ menyatakan puas dengan perilaku caring perawat, dan 3 orang responden atau $(8,1 \%)$ menyatakan cukup puas. Sehingga berdasarkan data diatas, didapatkan hasil bahwa sebagian besar resonden menyatakan sangat puas dengan pelayanan yang diberikan oleh perawat.

Pada penelitian ini, peneliti ingin mengetahui bagaimana hubungan antara perilaku caring perawat dengan tingkat kepuasan orangtua bayi Puskesmas Blega Kabupaten Bangkalan.Untuk membuktikan hipotesis penelitian tentang apakah terdapat hubungan antara perilaku caring perawat dengan tingkat kepuasan orangtua bayi, maka peneliti menggunakan uji korelasi spearman.Sehingga hasil data yang diperoleh adalah sebagai berikut:

Tabel 3. Tabulasi Silang dan Pengujian Korelasi Spearman

\begin{tabular}{|c|c|c|c|c|}
\hline \multirow[b]{2}{*}{$\begin{array}{c}\text { Prilaku } \\
\text { Caring }\end{array}$} & \multicolumn{4}{|c|}{ Tingkat Kepuasan } \\
\hline & $\begin{array}{c}\text { Cukup } \\
\text { Puas } \\
\text { f(\%) }\end{array}$ & $\begin{array}{l}\text { Puas } \\
\mathrm{f}(\%)\end{array}$ & $\begin{array}{c}\text { Sangat } \\
\text { Puas } \\
\mathrm{f}(\%)\end{array}$ & $\begin{array}{l}\text { Total } \\
\mathbf{f}(\%)\end{array}$ \\
\hline Cukup & $\begin{array}{c}3 \\
8,1 \%\end{array}$ & $\begin{array}{c}6 \\
16,2 \%\end{array}$ & $\begin{array}{c}2 \\
5,4 \%\end{array}$ & $\begin{array}{c}11 \\
29,7 \%\end{array}$ \\
\hline Baik & $\begin{array}{c}0 \\
0 \%\end{array}$ & $\begin{array}{c}6 \\
16,2 \%\end{array}$ & $\begin{array}{c}20 \\
54,1 \%\end{array}$ & $\begin{array}{c}26 \\
70,3 \%\end{array}$ \\
\hline Total & $\begin{array}{c}3 \\
8,1 \%\end{array}$ & $\begin{array}{c}12 \\
32,4 \%\end{array}$ & $\begin{array}{c}22 \\
59,5 \%\end{array}$ & $\begin{array}{c}37 \\
100 \%\end{array}$ \\
\hline & & & & $\begin{aligned} \operatorname{sig} & =0.000 \\
r & =0.592\end{aligned}$ \\
\hline
\end{tabular}

Perilaku caring perawat pada

kategori cukup sebanyak $29,7 \%$ orang 
dimana paling banyak merasa puas yaitu $16,2 \%$. Sedangkan pada kategori baik sebanyak $70,3 \%$ orang dimana paling banyak merasa sangat puas yaitu $59,5 \%$. Dari hasil pengujian korelasi didapatkan nilai sig sebesar 0,000. Nilai tersebut $<0,05$ sehingga hipotesis yang menyatakan terdapat hubungan antara perilaku caring perawat dan tingkat kepuasan orangtua bayi diterima. Besarnya korelasi adalah 0,592 yang masuk dalam kategori cukup kuat.Arah hubungan dari korelasi tersebut adalah positif yang bermakna sejajar, yaitu jika perilaku caring perawat semakin baik maka orangtua semakin puas bahkan sangat puas.

Berdasarkan hasil tabulasi silang, didapatkan data dari 37 responden bahwa perilaku caring perawat yang baik dengan tingkat kepuasan sangat puas paling banyak dengan jumlah 20 responden atau 54,1\%. Perilaku caring baik dengan tingkat kepuasan puas yaitu sebanyak 6 responden atau $16,2 \%$, perilaku caring perawat cukup dengan tingkat kepuasan sangat puas sebanyak 2 responden atau 5,4\%, perilaku caring perawat cukup dengan tingkat kepuasan puas 16,2\% sebanyak 6 responden dan perilaku caring perawat cukup dengan tingkat kepuasan cukup puas $8,1 \%$ atau sebayak 3 responden.

Hasil diatas, menunjukkan bahwa lebih dari $50 \%$ responden atau 20 responden merasa sangat puas dengan perilaku caring perawat yang baik sehingga hal ini dapat menjawab hipotesa yaitu terdapat hubungan perilaku caring perawat dengan tingkat kepuasan orangtua di ruang anak Puskesmas
Blega. Hal tersebut juga didukung hasil tabulasi 10 caratif faktor yang mempengaruhi perilaku caring perawat dan tingkat kepuasan responden berdasarkan dimensi mutu layanan.

Salah satu faktor dari 10 caratif factor yang paling mempengaruhi penilaian responden adalah faktor Promote expression of feelings (menerima dan meningkatkan ungkapan positif dan negatif). Pada faktor tersebut didapatkan hasil bahwa 70,3\% orangtua menyatakan setuju dan 29,7\% responden menyatakan sangat setuju. Hal tersebut menunjukkan bahwa perawat di ruangan memberikan perhatian terhadap keluhan orangtua dan mendengarkan dengan penuh perhatian sehingga orangtua tidak merasa cemas dengan keadaan bayinya.Pernyataan diatas sesuai dengan teori yang dikeumukakan oleh Watson (2010) yaitu, caring menuntut perawat untuk mampu meningkatkan harga diri seorang klien dengan memperhatikan segala kelebihan dan kekurangan klien dalam menghadapi masalahnya.

Adapun apabila dikaji berdasarkan dimensi mutu klien, hasil penelitian bahwaterdapat hubungan antara perilaku caring perawat dengan tingkat kepuasan orangtua di ruang rawat inap anak Puskesmas Blega Kabupaten Bangkalan didapatkan hasil bahwa pada lebih dari 50\% responden merasa puas dengan dimensi kehandalan (reliability) yang dilakukan oleh perawat di ruangan. Hal tersebut dibuktikan dengan sebanyak51,4\% responden menyatakan sangat puas untuk pernyataan 3 dan $56,8 \%$ responden 
puasuntuk pernyataan 4. Hasil penelitian pada dimensi ini menunjukkan bahwa responden merasa perawat dapat diandalkan dan tepat waktu dalam memberikan pelayanan sehingga sesuai dengan harapan mereka. Pernyataan diatas sesuai dengan pernyataan Rahmulyono (2008), salah satu faktor yang berpengaruh terhadap kepuasan adalah mutu informasi yang diterima seperti apa yang dikerjakan dan apa yang dapat diharapkan. Pernytaan tersebut sesuai dengan Equity Theory oleh Stacy Adam bahwa orang akan merasa puas tergantung pada apakah ia merasakan keadilan (Equity) atau tidak atas suatu situasi. Jika input dan outputnya sama apabila dibandingkan dengan input dan output orang/jasa yang dijadikan perbandingan maka kondisi itu disebut puas (Haryati dan Hadi, 2006).

Hasil penelitian ini sesuai dengan hasil penelitian sebelumnya yang dilakukan oleh Putri (2014) dengan penelitian untuk menganalisis hubungan perilaku caring perawat dengan tingkat kepuasan pasien di ruang rawat inap RSUD Soeroto Ngawi. Dari hasil penelitian tersebut menunjukkan bahwa $50,7 \%$ responden mempunyai presepsi bahwa perawat memiliki perilaku caring baik dan menunjukkan kepuasan terhadap pelayanan keperawatan. Hasil uji spearmen (r) menunjukkan 0,001 (p<0,005) yang menunjukkan terdapat hubungan antara perilaku caring perawat dengan tingkat kepuasan responden di ruang rawat inap RSUD Soeroto Ngawi.

Hasil ini juga sama dengan penelitian sebelumya yang dilakukan oleh Umi Kalsum
(2016) yang berjudul hubungan perilaku caring perawat dengan tingkat kepuasan pasien di ruang perawatan teratai RSUP Fatmawati. Hasil penelitian menunjukkan bahwa perilaku caring yang dilakukan perawat ruangan tersebut dinilai $74 \%$ baik dan responden merasa puas dengan perilaku tersebut.Sehingga, terdapat hubungan anatara perilaku caring perawat yang baik tingkat kepuasan pasien yang puas. Hal ini sesuai dengan penelitian yang dilakukan oleh Francessa et.al (2016) dengan judul Parents' Perception of Satisfaction With Care From Pediatric Nurse

Practitioners Instrumentdimana berdasarkan penelitian tersebut dijelaskan bahwa orangtua melakukan penilaian terhadap pelayanan keperawatan yang diberikan oleh perawat anak yang meliputi skill komunikasi, ekspert di klinik, perilaku caring dan pengambilan keputusan dengan menggunakan PPSC-PNP. Hasil penilaian tersebut menunjukkan adanya kepuasan orangtua terhadap pelayanan keperawatan yang diberikan oleh perawat antara lain salah satunya perilaku caring perawat rentang skor 6- 30 dengan $\mathrm{SD}=$ 3.37 .

\section{PENUTUP}

\section{Kesimpulan}

Hasil penelitian dari perilaku caring perawat ruang rawat inap anak Puskesmas Blega Kabupaten Bangkalan menunjukkan bahwa dari 37 responden sebanyak 26 responden atau $(70,3 \%)$ menyatakan perilaku caring perawat baik dan sebanyak 11 responden $(29,7 \%)$ menyatakan perilaku 
caring cukup. Sehingga dapat disimpulkan bahwa perilaku caring perawat di ruang anak tersebut masuk ke dalam kategori baik atau cukup baik.

Hasil penelitian tingkat kepuasan orangtua di ruang rawat inap anak Puskesmas Blega Kabupaten Bangkalan menunjukkan bahwa dari 37 responden 22 orang diantaranya merasa sangat puas $(59,5 \%)$, sedangkan 12 orang $(32,4 \%)$ merasa puas dan sebanyak 3 orang atau $(8,1 \%)$ memiliki tingkat kepuasan cukup puas sehingga dapat disimpulkan bahwa tingkat kepuasan orangtua bayi terkait pelayanan yang diberikan di ruangan tersebut secara keseluruhan adalah sangat puas.

Hasil penelitian ini menunjukkan nilai korelasi spearmen rank/rho (+) 0,592 yang menunjukkan bahwa hubungan antara perilaku caring perawat dengan tingkat kepuasan orangtua termasuk dalam kategori cukup kuat. Arah hubungan yang positif menunjukkan bahwa dengan perilaku caring perawat yang baik akan memberikan tingkat kepuasan yang puas bahkan sangat puas kepada orangtua bayi.

\section{Saran}

Sebaiknya dalam memberikan asuhan keperawatan tidak hanya berfokus pada pemenuhan kebutuhan dasar pasien saja tetapi perawat juga sebaiknya melakukan caring pada paseien dan keluarga untuk mengurangi stres pada saat perawatan sehingga kepuasan dalam pemberian asuhan keperawatan dapat tercapai dengan baik. Untuk peneliti selanjutnya coba untuk meneliti tentang faktor lain yang mempengaruhi tentang kepuasan sebagai contoh faktor. Kualitas pemberi layanan asuhan keperawatan, pembiayaan perawatan dll yang mungkin faktor tersebut memiliki hubungan yang lebih signifikan.

\section{DAFTAR PUSTAKA}

Abdul Saleh, A. (2013) 'hubungan perilaku caring perawat dengan tingkat kepuasan pasien perawat rawat inap rumah sakit kota baubau'.

Aris, W. (2016) 'Hubungan peran caring perawat terhadap kualitas pelayanan keperawatan berdasarkan indikator keselamatan pasiendi rumah sakit dr Soepraoen Malang'.

Chotimah, N. (2016) 'hubungan perilaku caring perawat degan tingkat kecemasan keluarga pasien di ruang intensif care unit (ICU) RSUD Tugurejo Semarang'.

Dwi, W. (2016) 'hubungan perilaku caring dengan tingkatkepuasan pasien di ruang bedah rumah sakit TK II dr soepraoen malang'.

Kemenkes (2011) Lampiran Peraturan Menteri Kesehatan Republik Indonesia no 1171/menkes/per/IV/2011.

Whatson.Jean (2007) caring science 10 caritas process. 